Int. J. Morphol.,

35(3):950-957, 2017.

\title{
Morphology and Histology of the Pirarucu (Arapaima gigas) Digestive Tract
}

\author{
Morfología e Histología del Tubo Digestivo del Paiche (Arapaima gigas)
}

Rodrigues, Ana Paula Oeda ${ }^{1} \&$ Cargnin-Ferreira, Eduardo ${ }^{2}$

RODRIGUES, A. P. O. \& CARGNIN-FERREIRA, E. Morphology and histology of the pirarucu (Arapaima gigas) digestive tract. Int. J. Morphol., 35(3):950-957, 2017.

SUMMARY: The present study describes the morphology and histology of the digestive tract of juvenile pirarucu, which is a Neotropical fish species with great potential for aquaculture in the Amazon region. Three size classes of pirarucu juveniles from commercial fish farms were sampled for histological examination of the oesophagus, stomach, pyloric caeca, intestine and liver. The morphological and histological features of the pirarucu digestive tract are similar to other carnivorous teleosts and enable the species to ingest, store and digest large food items. Acidic and neutral mucins are secreted by the mucosa of the oesophagus, stomach, pyloric caeca and intestine to protect the mucosal epithelium and to lubricate and facilitate food passage along the digestive tract. Complex transverse folds are predominant in the intestinal mucosa and most likely contribute to optimization of the digestion and nutrient absorption processes, thereby offsetting the relatively short length of the intestine. The exocrine pancreas appears diffuse in the liver and mesentery around the pyloric region of the stomach, pyloric caeca and initial part of the intestine. The digestive tract morphology and thickness become increasingly developed with the size of pirarucu.

KEY WORDS: Aquaculture; Fish nutrition; Digestion; Absorption; Carnivorous; Osteoglossiformes.

\section{INTRODUCTION}

The morphology of the fish digestive tract evolved to ensure that ingestion, digestion and nutrient absorption were adapted to the food habits of the species. Thus, the development of specific feeds for different species of fish and the establishment of appropriate feeding strategies should consider not only their eating habits and behaviours but also the anatomical and morphophysiological traits of the digestive system (Pezzato et al., 2004).

Several studies (Albrecht et al., 2001; Hernández et al., 2009; L økka et al., 2013, Faccioli et al., 2014) describing the digestive systems of fish have been conducted to elucidate the nutritional dynamics as well as pathological and physiological changes in target aquaculture species. Complementarily, histological examinations of the digestive tract and accessory organs have been used as an auxiliary tool for the nutritional assessment of diets and ingredients (mostly plant sources) for feed formulations (Baeverfjord \& Krogdahl, 1996; Krogdahl et al., 2015). These studies are particularly relevant for the nutrition of carnivorous fish species, which have reduced adaptive flexibility in response to changes in diet due to the decreased variation in the nutrient composition of their natural diets (Buddington et al., 1997).

Arapaima gigas (Osteoglossiformes: Arapaimatidae; commonly known as pirarucu) stands out among Neotropical fish. This large-sized, carnivorous species is of great commercial value and has great potential for aquaculture in the Amazon region. The pirarucu is an obligatory airbreathing freshwater species fish with accelerated and unequal growth (up to $10 \mathrm{~kg}$ in the first year) and excellent quality of its boneless meat. These characteristics and the decline of natural stocks due to overfishing render pirarucu quite attractive for fish farming (Lima et al., 2015). However,

\footnotetext{
${ }^{1}$ Empresa Brasileira de Pesquisa Agropecuária, Embrapa Pesca e Aquicultura, Prolongamento da Avenida NS 10, Cruzamento com Avenida LO 18, sentido Norte, Loteamento Água Fria, CEP: 77.008-900, Caixa Postal nº 90, Palmas, TO, Brazil. E-mail: anapaula.rodrigues@embrapa.br.

${ }^{2}$ Instituto Federal de Santa Catarina, Campus Garopaba, Rua Maria Aparecida Barbosa, no 153, Campo Duna, CEP 88495-000, Garopaba, SC, Brazil. This study is part of the "Amazon Pirarucu Project - Research and Technology Transfer" funded by the Brazilian Micro and Small Business Support Service/Scientific and Technological Support Foundation of Tocantins (SEBRAE/FAPTO) and the Ministry of Agriculture, Livestock and Supply/ Brazilian National Council for Scientific and Technological Development (MAPA/CNPq) (grant number 434400/2016-5].
} 
technological bottlenecks in the reproduction, health and nutrition fields are significant obstacles in the development of its farming (Lima et al.). In the field of nutrition, research studies with pirarucu are still relatively recent and scarce, with little knowledge available on the morphology of its digestive system. The present study describes the morphology and histology of the digestive tract of juvenile pirarucu to better understand the nutrient use strategies of the species and to provide basis for further research studies covering its nutrition and health.

\section{MATERIAL AND METHOD}

Three size classes of juvenile pirarucu were purchased from a fish farm in the state of Tocantins (Brazil), where they were fed commercial feed for carnivorous fish (40\% - $45 \%$ crude protein). After fasting for 48-72 hours, the fish were euthanized by eugenol overdose, and the weight and the standard length of each individual were recorded (Table I). Then, the fish were laparotomized to collect the oesophagus, stomach, pyloric caeca, mid-gut, rectum and liver. The length of the intestine was measured to calculate the intestinal coefficient (length of the intestine/standard length) before dividing the organ into two sections (mid-gut and rectum) (Bértin, 1958). The mid-gut accounted for approximately $95 \%$ of the total length of the intestine and was divided into the following segments for histological examination: the anterior (S1), intermediate (S2) and posterior (S3) segments (approximately 25, 60 and $15 \%$ of the mid-gut length, respectively).

The samples were immediately fixed in $4 \%$ formalin in $0.1 \mathrm{M}$ phosphate buffer $(\mathrm{pH} \mathrm{7.2)}$ for $24 \mathrm{~h}$. Then, the samples were rinsed in distilled water, followed by dehydration in increasing concentrations of ethanol (70, 90 and $100 \%)$. The tissues were embedded in glycolmethacrylate resin (Leica Historesin Embedding Kit, Heidelberg, Germany) and/or paraffin and sectioned into 3to $5-\mu \mathrm{m}$ non-sequential sections. The oesophagus (middle portion), stomach (anterior and posterior) and liver were cross-sectioned, whereas the pyloric caeca and intestine were sectioned longitudinally. Papanicolaou and haematoxylin and eosin staining methods were used for general observation of morphological structures. Class III fish tissues were

Table I Weight, standard length and intestinal coefficient of three size classes of pirarucu juveniles (mean \pm standard deviation).

\begin{tabular}{ccccc}
\hline Size class & Weight $(\mathrm{g})$ & Standard length $(\mathrm{cm})$ & Intestinal coefficient & $\mathrm{n}$ \\
\hline I & $3.33 \pm 0.90$ & $7.04 \pm 0.58$ & $0.94 \pm 0.14$ & 7 \\
II & $72.07 \pm 5.28$ & $20.07 \pm 0.35$ & $1.00 \pm 0.44$ & 7 \\
III & $1,328.10 \pm 305.89$ & $52.91 \pm 3.97$ & $1.30 \pm 0.06$ & 7 \\
\hline
\end{tabular}

Stomach. The J-shaped stomach of pirarucu is quite muscular and distensible. It has two anatomically and histologically distinguishable regions: the corpus, proximal and larger region, which is characterized by a fairly folded mucosa; and the pylorus, distal region, which is relatively more muscular with shallower folds. In both regions, the folds are longitudinal. The gastric mucosa consists of a single layer of columnar epithelial cells that secrete neutral and acidic mucosubstances and exhibit a strong reaction with PAS and a moderate affinity for $\mathrm{AB}$ (Fig. 2A, B and C). The coexistence of acidic and neutral mucins in the epithelium was identified by the purplish staining of some cells with $\mathrm{AB}$ $\mathrm{pH}$ 2.5/PAS (Fig. 2D). A greater quantity of mucus was usually observed around the pyloric mucosa, which showed a stronger reaction with $\mathrm{AB} \mathrm{pH} 2.5$ compared to the gastric corpus (Fig. $2 \mathrm{~A}$ and $\mathrm{B})$. Simple tubular glands only occurred 
in the lamina propria of the corpus (Fig. 3A) and became increasingly abundant with increasing pirarucu size. The tunica muscular of the corpus consisted of an internal oblique layer of smooth muscle tissue, with bundles invading the gastric submucosa, and an outer circular layer (Fig. 3A). A thick circular muscular layer was predominant in the pylorus (Fig. 3B). Pancreatic acini were often observed around the pylorus (not shown).
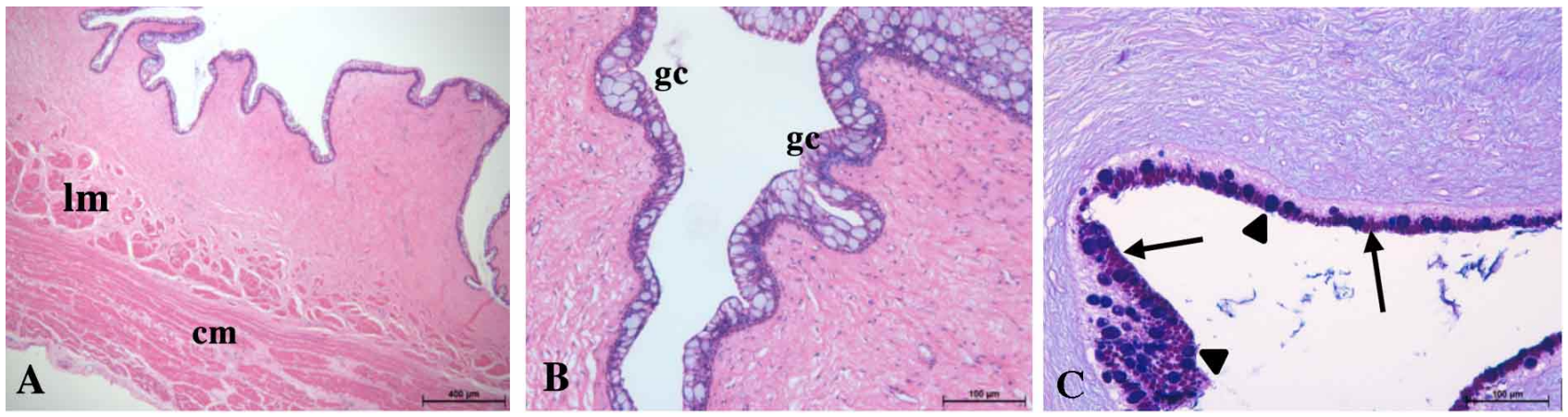

Fig. 1 Oesophagus of size class III pirarucu. (A) and (B) Deep and longitudinal mucosal folds, stratified epithelium, goblet cells (gc), dense connective tissue with no distinction between the lamina propria and submucosa, and tunica muscularis composed of an inner longitudinal striated muscular layer $(\mathrm{lm})$ and an outer circular layer $(\mathrm{cm})$ (Haematoxylin and eosin stain; x50 and x200, respectively). (C) Large (arrowheads) and small (arrows) goblet cells stained in purplish-blue and red, respectively, with Alcian blue $\mathrm{pH} 2.5 / \mathrm{periodic}$ acidSchiff (x200).

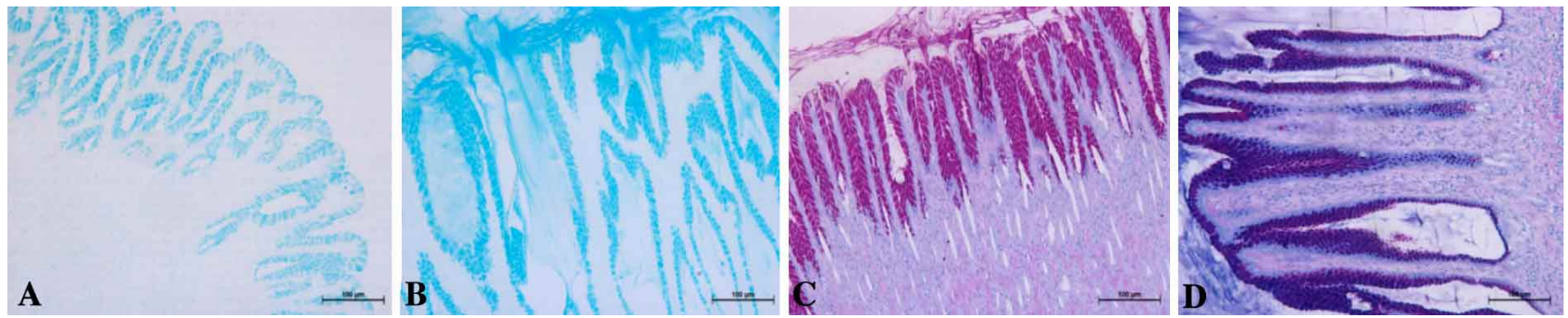

Fig. 2 Histochemistry of mucosubstances secreted by the gastric epithelium of size class III pirarucu. (A) Corpus and (B) pyloric regions showing moderate affinity for Alcian blue at pH 2.5 (x200). (C) Neutral apical mucins in the gastric corpus with intense periodic acidSchiff positivity (x200). (D) Epithelium of the pyloric region showing apical mucins stained purplish-blue and red with Alcian blue at pH 2.5/periodic acid-Schiff (x200).
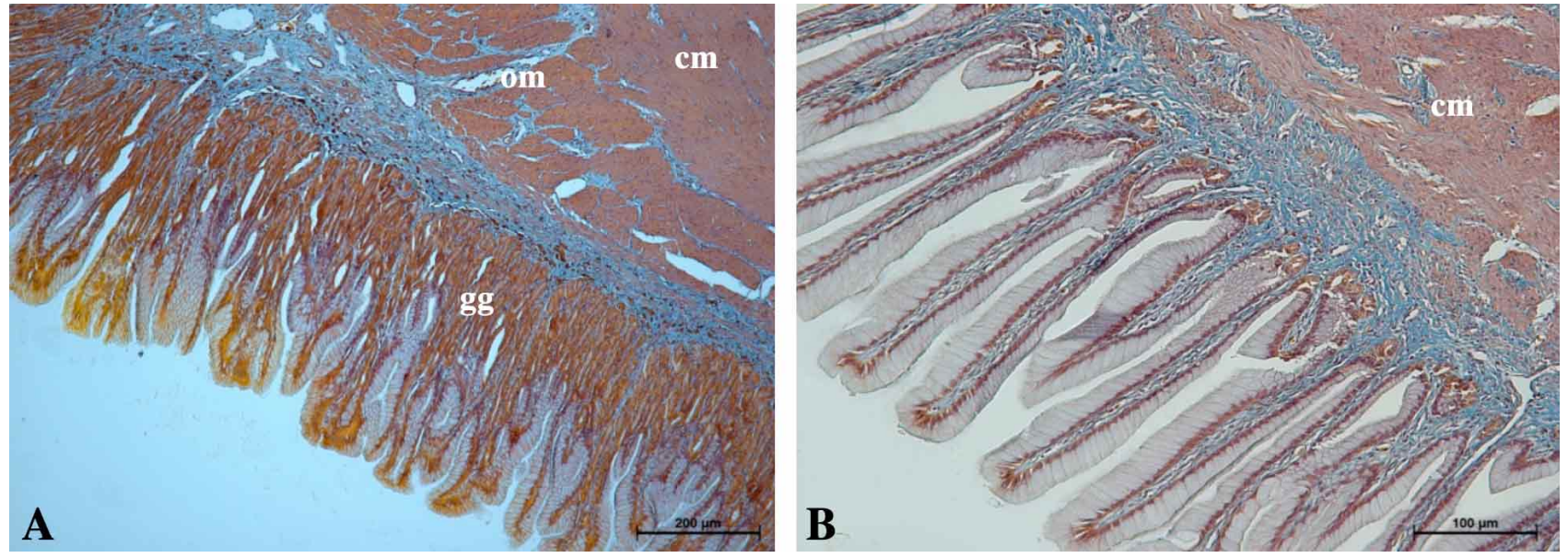

Fig. 3 (A) Corpus and (B) pyloric regions of the stomach of size class II pirarucu. Compared to the pyloric region, the gastric corpus presents simple tubular gastric glands (gg) and a tunica muscularis composed of smooth muscle arranged in inner oblique (om) and outer circular layers (cm) (Papanicolaou stain; x100, x200, respectively). 
Pyloric caeca, medium intestine and rectum. The pirarucu intestine is a relatively short tube with an intes- tinal coefficient close to 1.0 (Table I). Its beginning is marked by the presence of two pyloric caeca of different
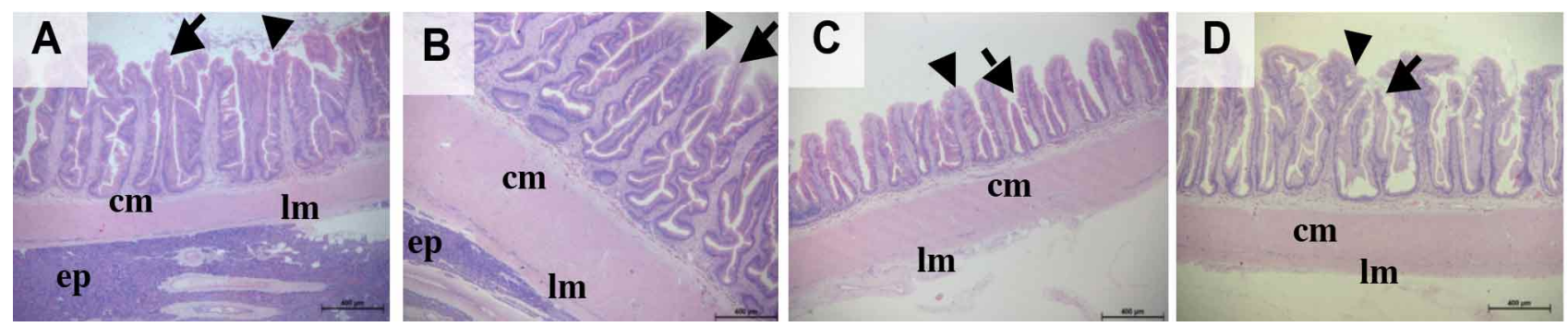

Fig. 4 (A) Pyloric caecum and (B, C, and D) mid-gut of size class III pirarucu (anterior, intermediate, and posterior segments - S1, S2, and S3, respectively) showing simple (arrows) and complex folds (arrowheads). The tunica muscularis is composed of smooth muscle arranged in inner circular $(\mathrm{cm})$ and outer longitudinal $(\mathrm{lm})$ layers. The exocrine pancreas (ep) is observed in the pyloric caecum and $\mathrm{S} 1$ (Haematoxylin and eosin stain; x50).
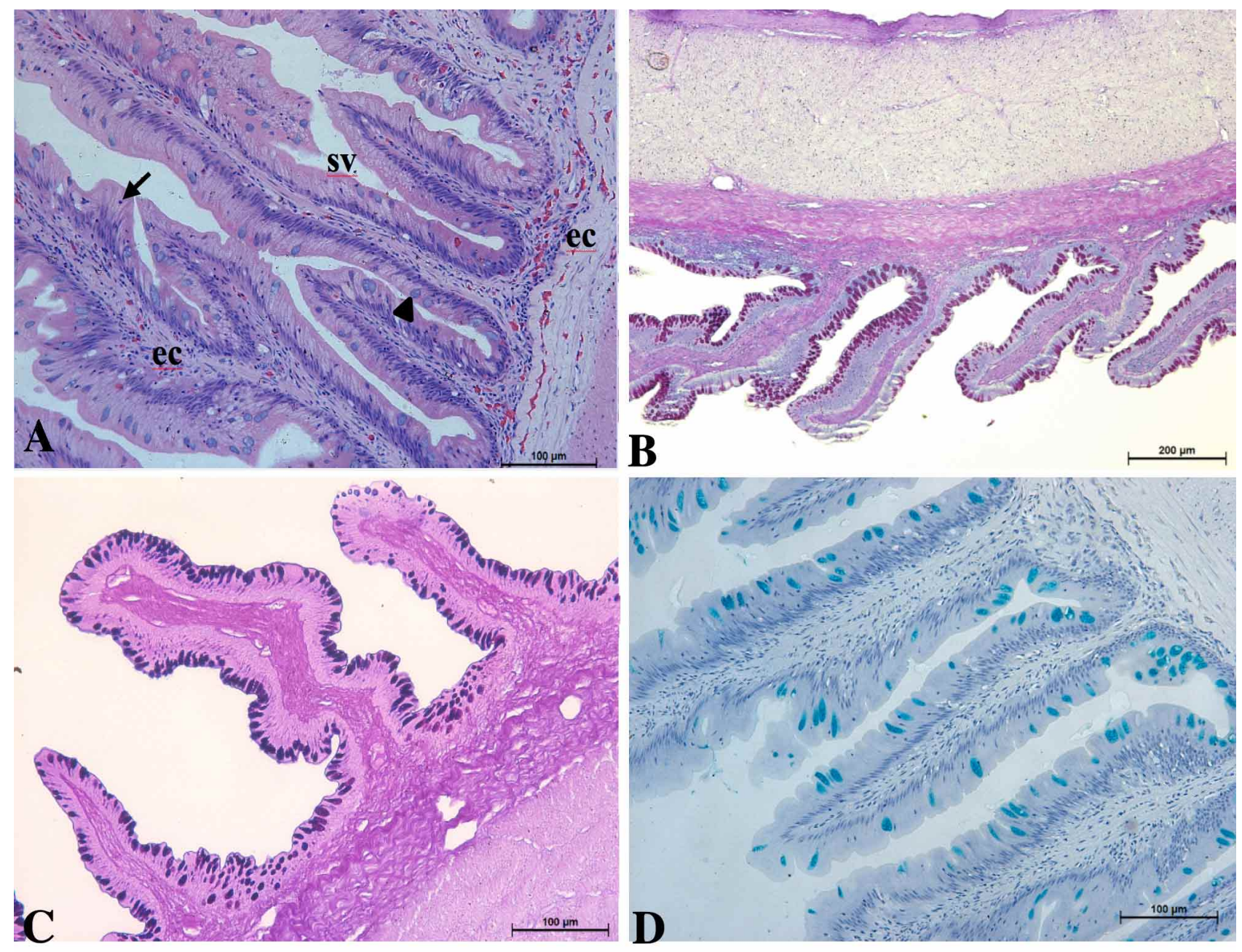

Fig. 5 Intestine of size class III pirarucu. (A) Posterior segment of the mid-gut (S3) with mucosa presenting a simple columnar epithelium with supranuclear vacuoles (sv), some goblet cells (arrowhead) and lymphocytes (arrow). Eosinophilic cells (ec) are seen in the lamina propria and submucosa (haematoxylin and eosin stain; x200). (B and C) Rectum showing simple folds, a high density of goblet cells secreting neutral and acid mucins, dense connective tissue in the submucosa, and a thick muscular layer (periodic acid-Schiff/haematoxylin and Alcian blue at $\mathrm{pH}$ 2.5/periodic acid-Schiff stain; $\mathrm{x} 100$ and x200, respectively). (D) Goblet cells of the intermediate segment of the mid-gut (S2) exhibiting high affinity with Alcian blue at $\mathrm{pH}$ 2.5/haematoxylin (x200). 
lengths. The absence of an ileorectal valve hinders the distinction between the mid-gut and rectum, and the latter is differentiated from the former by its flattened shape. The mid-gut begins as an ample tube (S1) that gradually decreases in diameter until stabilizing (S2) and then subsequently becomes relatively larger again (S3).

The mid-gut and pyloric caeca of pirarucu are histomorphologically similar (Fig. 4A-D). The mucosal folds are predominantly transverse to the respective organs, with simple folds usually interspersed with more complex (branched) folds (Fig. 4A-D). In the pyloric caeca and S1, the folds are slightly higher and more branched than in S2 and S3 (Fig. 4A-D). The architecture of the mucosal folds becomes increasingly more complex with the size of the pirarucu, and a significant increase in the tunica muscular thickness is also observed. The mucosa is formed by a simple columnar epithelium with a clear brush border and interspersed goblet cells and lymphocytes (Fig. 5A). The mucosal lamina propria has eosinophilic granular cells, which are noticeably more abundant in the boundary between the lamina propria and submucosa (Fig. 5A). The muscular layer consists of smooth muscle cells that form an inner circular and outer longitudinal layer (relatively thinner than the former (Fig. 4A-D). Fairly vascularized pancreatic acini were observed around the pyloric caeca and in the initial portion of S1 (Fig. 4A and B). In S3, supranuclear vacuoles were often observed in the enterocytes (Fig. 5A).
Compared to the mid-gut, the pirarucu rectum showed a higher occurrence of goblet cells in the mucosa, a thicker submucosa formed by denser connective tissue and a more developed muscular layer (Fig. 5B and C). The rectal mucosal folds are longitudinally oriented and typically simple with few branches (Fig. 5B and C).

The same histochemical pattern was observed in the goblet cells of the pyloric caeca, mid-gut and rectum, which stained intensely with PAS and $\mathrm{AB}$ pH 2.5 and showed a high number of purplish (associated neutral and acidic mucins) and some reddish (neutral mucins) cells when stained with $\mathrm{AB}$ pH 2.5/PAS (Fig. 5B, C and D).

\section{Liver}

The pirarucu liver is a unique organ. The hepatic parenchyma mostly consists of polyhedral hepatocytes with central nuclei and variable glycogen and lipid deposits in the cytoplasm (Fig. 6A). Typical hepatic lobules are not found in the parenchyma. However, portal spaces with typical triads (branch of the hepatic artery, portal vein branch and a bile duct) are found scattered throughout the parenchyma (Fig. 6B). The exocrine pancreas appears diffuse in the pirarucu liver as pancreatic acini (Fig. 6A). Each acinus consists of pyramidal cell clusters with many eosinophilic zymogen granules in their apical regions. A branched system of excretory ducts of varying sizes is noticeably associated with the pancreas (Fig. 6A).
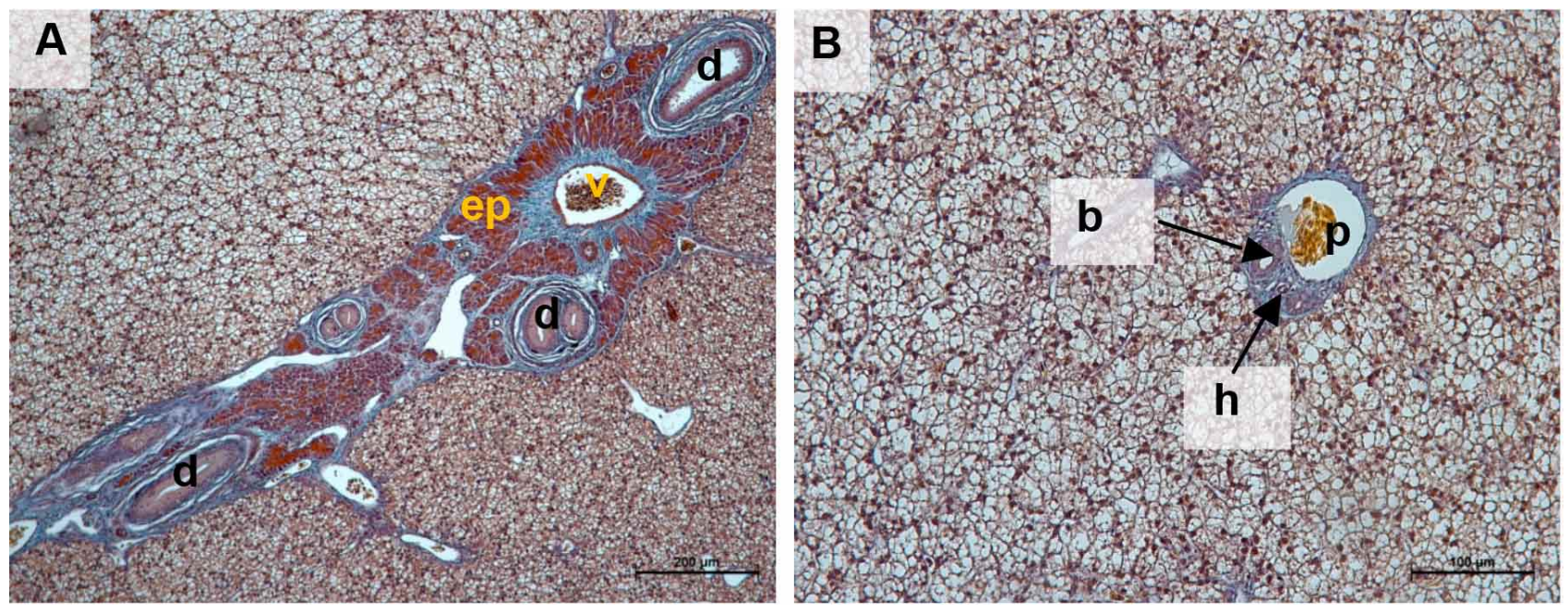

Fig. 6 (A) Hepatic parenchyma of size class II pirarucu exhibiting hepatocytes with variable cytoplasmic lipid and/or glycogen deposits. The exocrine pancreas (ep) appears organized in pancreatic acini with a branched excretory ductile system (d). A longitudinal section of a pancreatic-venous tract with a portal afferent vein with erythrocytes inside of it (v) is also observed. (B) Detail of a portal space with a typical triad: branch of the hepatic artery (ha), branch of the portal vein (pv) and bile duct (bd). (Papanicolaou stain; x100, x200, respectively). 


\section{DISCUSSION}

The oesophagus is the region through which food passes from the mouth to the stomach and usually consists of a short, straight and muscular tube in fish (Wilson \& Castro, 2011). The oesophagus is particularly elastic in predatory fish (Rust, 2002), and thus the pirarucu oesophagus features deep folds and dense, thick connective tissue in the mucosa and submucosa that help protect oesophageal wall integrity against sudden distensions during prey ingestion (Albrecht et al.). A fairly developed mucosa with numerous thick longitudinal folds was also observed in the oesophagus of the carnivorous dourado Salminus brasiliensis and was regarded as an adaptation for oesophageal distension and food passage (Rodrigues \& Menin, 2008). Complementarily, the stratified epithelium and high number of goblet cells found in pirarucu and other fish species protect the oesophagus against mechanical and chemical injuries and lubricate food passage (Albrecht et al.; Wilson \& Castro). Two types of goblet cells were also identified in the oesophageal mucosa of the Nile tilapia Oreochromis niloticus by Morrison \& Wright (1999). The authors suggested that each type of cell produced different secretions based on differences in affinity to $\mathrm{AB} \mathrm{pH}$ 2.5/ PAS, which may also occur in pirarucu.

The J-shaped stomach of pirarucu is the stomach shape most commonly found in fish species (Wilson \& Castro) and has been described for both carnivorous (Løkka et al.; Faccioli et al.) and omnivorous (Hernández et al.) species. The division into corpus (proximal and glandular region) and pylorus (distal and aglandular region) has also been used for other fish species (Reifel \& Travill, 1978; Ostos Garrido et al., 1996). The large stomach volume of pirarucu and the presence of deep, longitudinal folds and a fairly developed tunica muscularis aid stomach distension and the storage of large food quantities (Rodrigues \& Menin). Furthermore, the high occurrence of gastric glands in the corpus region, particularly in size class III fish, may be related to the carnivorous feeding habits of the species. Similarly, the abundance of gastric glands in the anterior region of the stomach of the carnivorous Hemisorubim platyrhynchos was attributed to the need to digest large prey (Faccioli et al.). Although the function of the pylorus is primarily related to gastric emptying (Rodrigues \& Menin), its increased muscle thickening in pirarucu may contribute to the final mechanical digestion of the food bolus.

The tunica muscularis of the fish digestive tract is usually organized into circular and longitudinal layers; however, a third oblique layer may occasionally occur (Takashima \& Hibiya, 1995; Hernández et al.). The existence of an oblique muscular layer in the pirarucu stomach should enhance mucosal fold movements, thereby enabling increased efficiency in mixing food with gastric juices, similar to the function attributed to the muscularis mucosae (Albrecht et al.).

The neutral and acidic mucosubstances secreted by the gastric mucosal epithelium play an important role in controlling the stomach $\mathrm{pH}$, protecting the epithelium from the gastric juices, and facilitating the passage of large food items (Ostos Garrido et al.; Wilson \& Castro). Similar to observations in pirarucu, the predominance of neutral mucins and the low occurrence of acidic mucins in the gastric epithelium (Reifel \& Travill, 1978; Ostos Garrido et al.; Carrassón et al., 2006; Faccioli et al.) as well as the combined production of both (Ostos Garrido et al.) were reported in other fish species.

The highly branched folds and relatively short intestine of pirarucu are typical of carnivorous fish species, which mostly offset the short length of the intestine with a fairly well folded absorptive surface (Reifel \& Travill, 1979; Buddington et al.; Rust). The presence of two pyloric caeca with similarly folded mucosa increases the area available for digestion and nutrient absorption (Buddington \& Diamond, 1987, Buddington et al.; Albrecht et al.).

Circular and transverse intestinal folds were also observed by Løkka et al., in the posterior mid-gut of the Atlantic salmon Salmo salar. The authors related this orientation to two possible functions: (i) integrated action of folds with the circular muscular layer to facilitate defecation and (ii) adaptation to slow the passage of chime through the intestinal tract. In pirarucu, circular and transverse folds are predominant throughout the mid-gut and pyloric caeca and most likely contribute to slow the passage of the chime through the intestine, thereby prolonging its intestinal permanence for the digestion and nutrient absorption processes.

Larger and more complex folds are often observed in the initial region of the mid-gut and pyloric caeca of several fish species (Reifel \& Travill, 1979; Faccioli et al.). The proximal portions of the intestines of fish are related to higher capacity and effective contribution to digestion and nutrient absorption, while the distal region is involved in the absorption of intact proteins and peptides (Krogdahl et al., 2003) - an ability that is related to its immunological role (Buddington et al.). In pirarucu, the latter function is most likely performed in the $\mathrm{S} 3$ region, where absorption vacuoles were often observed in the apical cytoplasm of enterocytes, which can be indicative of protein absorption by pinocytosis (Ezeasor \& Stokoe, 1981; Carrassón et al.). 
Simpler and shorter folds, abundant goblet cells and a thicker muscular layer are commonly observed features in the rectum of several fish species (Reifel \& Travill, 1979; Carrassón et al.). The increased number of goblet cells in that intestinal region is related to mucosal protection and faecal lubrication, whereas muscular layer thickening is associated with faecal expulsion. As reported for the pirarucu oesophagus, the occurrence of dense connective tissue in the rectal submucosa is most likely involved in protection against distension (Reifel \& Travill, 1979).

The pirarucu liver has histological features common to most fish species, including the absence of typical liver lobes, liver tissue that mostly consists of hepatocytes that store glycogen and lipids, and a complex network of blood vessels, ducts and sinusoids that facilitate constant exchanges between the circulatory system and the liver (Rust; Morrison et al., 2006). The exocrine pancreas was found in the liver parenchyma of pirarucu and was also histologically visualized scattered in the mesenteries around the pyloric region of the stomach, pyloric caeca and initial part of S1, thereby corroborating the diffuse pancreas presentation reported in most teleost fish (Rust; Morrison et al.). Digestive enzymes typical of the gut were quantified in the stomachs of the pintado Pseudoplatystoma corruscans (Lundstedt et al., 2004) and the tambaqui Colossoma macropomum (Almeida et al., 2006) and most likely reflect the presence of pancreatic tissue around the stomach. Enzymatic studies of pirarucu should consider the pyloric stomach region alongside the pyloric caeca, initial region of the intestine, and liver.

The morphology and histology of the pirarucu digestive tract are similar to other carnivorous teleosts and enable the species to ingest, store and digest large food items. The morphology and orientation of the intestinal mucosal folds contribute to the optimization of the digestion and nutrient absorption processes and offset the relatively short length of the intestine. In addition to these processes, the posterior region of the pirarucu mid-gut most likely plays an immunological role. All of these adaptations should be considered in future studies to assess feeding strategies and feed formulations for pirarucu.

RODRIGUES, A. P. O. \& CARGNIN-FERREIRA, E. Morfología e histología del tubo digestivo del paiche (Arapaima gigas). Int. J. Morphol. 35(3):950-957, 2017.

RESUMEN: El presente trabajo describe la morfología e histología del tracto digestivo de una especie juvenil de paiche, un pez neotropical con gran potencial acuícola en la region Amazónica. Se tomaron muestras de tres clases de tamaño de juveniles de paiche de granjas acuícolas comerciales para examen histológico del esófago, estómago, ciego pilórico, intestino e hígado. El tracto digestivo del paiche tiene características morfológicas e histológicas comunes a otros teleósteos carnívoros que permiten a la especie la ingestión, el almacenamiento y la digestión de grandes alimentos. Mucinas ácidas y neutras son secretadas por la capa mucosa del esófago, estómago, ciego pilórico e intestino para proteger el epitelio de esta capa, además de lubricar y facilitar el paso de los alimentos a lo largo del tracto. Pliegues complejos y de orientación transversal son predominantes en la mucosa intestinal, contribuyendo, probablemente, a la optimización de los procesos de digestión y absorción de nutrientes, y compensando la longitud relativamente corta del intestino. El páncreas exócrino se encuentra difuso dentro del hígado y en el mesenterio alrededor de la región pilórica del estómago, ciego pilórico y porción inicial del intestino. La morfología y el espesor del tubo digestorio se desarrollan de forma gradual a medida que el paiche crece.

PALABRAS CLAVE: Acuicultura; Nutrición de peces; Digestión; Absorción; Carnívoro; Osteoglosiformes.

\section{REFERENCES}

Albrecht, M. P.; Ferreira, M. F. N. \& Caramaschi, E. P. Anatomical features and histology of the digestive tract of two related neotropical omnivorous fishes (Characiformes; Anostomidae). J. Fish Biol., 58(2):419-30, 2001.

Almeida, L. C.; Lundstedt, L. M. \& Moraes, G. Digestive enzyme responses of tambaqui (Colossoma macropomum) fed on different levels of protein and lipid. Aquac. Nutr., 12(6):443-50, 2006.

Baeverfjord, G. \& Krogdahl, A. Development and regression of soybean meal induced enteritis in Atlantic salmon, Salmo salar L., distal intestine: a comparison with the intestines of fasted fish. J. Fish Dis., 19(5):37587, 1996.

Bértin, L. Appareil Digestif. In: Grassé, P. P. (Ed.). Traité de Zoologie. Vol 13. Paris, Masson, 1958. pp.1249-301.

Buddington, R. K. \& Diamond, J. M. Pyloric ceca of fish: a "new" absorptive organ. Am. J. Physiol., 252(1 Pt. 1):G65-76, 1987.

Buddington, R. K.; Krogdahl, A. \& Bakke-Mckellep, A. M. The intestines of carnivorous fish: structure and functions and the relations with diet. Acta Physiol. Scand., 638:67-80, 1997.

Carrassón, M.; Grau, A.; Dopazo, L. R. \& Crespo, S. A histological, histochemical and ultrastructural study of the digestive tract of Dentex dentex (Pisces, Sparidae). Histol. Histopathol., 21(6):579-93, 2006.

Ezeasor, D. N. \& Stokoe, W. M. Light and electron microscopic studies on the absorptive cells of the intestine, caeca and rectum of the adult rainbow trout, Salmo gairdneri, Rich. J. Fish Biol., 18(5):527-44, 1981.

Faccioli, C. K.; Chedid, R. A.; do Amaral, A. C.; Franceschini Vicentini, I. B. \& Vicentini, C. A. Morphology and histochemistry of the digestive tract in carnivorous freshwater Hemisorubim platyrhynchos (Siluriformes: Pimelodidae). Micron, 64:10-9, 2014.

Hernández, D. R.; Pérez Gianeselli, M. \& Domitrovic, H. A. Morphology, histology and histochemistry of the digestive system of South American Catfish (Rhamdia quelen). Int. J. Morphol., 27(1):105-11, 2009.

Krogdahl, A.; Bakke-McKellep, A. M. \& Baeverfjord, G. Effects of graded levels of standard soybean meal on intestinal structure, mucosal enzyme activities, and pancreatic response in Atlantic salmon (Salmo salar L.). Aquac. Nutr., 9(6):361-71, 2003.

Krogdahl, Å.; Gajardo, K.; Kortner, T. M.; Penn, M.; Gu, M.; Berge, G. M. $\&$ Bakke, A. M. Soya Saponins Induce Enteritis in Atlantic Salmon 
(Salmo salar L.). J. Agric. Food Chem., 63(15):3887-902, 2015.

Lima, A. F.; Rodrigues, A. P. O.; Varela, E. S.; Torati, L. S. \& Maciel, P. O. Pirarucu culture in the Brazilian Amazon: fledgling industry faces technological issues. Glob. Aquac. Advocate, 18:56-8, 2015.

Løkka, G.; Austbø, L.; Falk, K.; Bjerkås, I. \& Koppang, E. O. Intestinal morphology of the wild Atlantic salmon (Salmo salar). J. Morphol., 274(8):859-76, 2013.

Lundstedt, L. M.; Melo, J. F. \& Moraes, G. Digestive enzymes and metabolic profile of Pseudoplatystoma corruscans (Teleostei: Siluriformes) in response to diet composition. Comp. Biochem. Physiol. B Biochem. Mol. Biol., 137(3):331-9, 2004.

Morrison, C. M. \& Wright Jr., J. R. A study of the histology of the digestive tract of the Nile tilapia. J. Fish Biol., 54(3):597-606, 1999.

Morrison, C. M.; Fitzsimmons, K. \& Wright Jr., J. R. Atlas of Tilapia Histology. Baton Rouge, The World Aquaculture Society, 2006.

Ostos Garrido, M. V.; González Oller, C. \& Abaurrea Equisoain, M. A. Effect of diet on gastric mucosa cells in the European eel (Anguilla anguilla L.). Histochemical and ultrastructural study. Micron, 27(1):2534, 1996.

Pezzato, L. E.; Barros, M. M.; Fracalossi, D. M. \& Cyrino, J. E. P. Nutrição de Peixes. In: Cyrino, J. E. P.; Urbinati, E. C.; Fracalossi, D. M. \& Castagnolli, N. (Eds.). Tópicos Especiais em Piscicultura de Água Doce Tropical Intensiva. São Paulo, TecArt, 2004. pp.75-169.

Reifel, C. W. \& Travill, A. A. Structure and carbohydrate histochemistry of the stomach in eight species of teleosts. J. Morphol., 158(2):155-67, 1978.

Reifel, C. W. \& Travill, A. A. Structure and carbohydrate histochemistry of the intestine in ten teleostean species. J. Morphol., 162(3):343-59, 1979.

Rodrigues, S. S. \& Menin, E. Anatomia do tubo digestivo de Salminus brasiliensis (Cuvier, 1817) (Pisces, Characidae, Salmininae). Biotemas, 21(2):65-75, 2008.

Rust, M. B. Nutritional Physiology. In: Halver, J. E. \& Hardy, R. W. (Eds.). Fish Nutrition. San Diego, Academic Press, 2002. pp.367-505.

Takashima, F. \& Hibiya, T. An Atlas of Fish Histology. Normal and Pathological Features. $2^{\text {nd }}$ ed. Tokyo, Kodansha Ltd., 1995.

Wilson, J. M. \& Castro, L. F. C. Morphological Diversity of the Gastrointestinal Tract in Fishes. In: Grosell, M.; Farrell, A. P. \& Brauner, C. J. (Eds). Fish Physiology: The Multifunctional Gut of Fish. New York, Academic Press, 2011. pp. 2-55.

\author{
Corresponding author: \\ Dr. Ana Paula Oeda Rodrigues \\ Empresa Brasileira de Pesquisa Agropecuária (Embrapa) \\ Embrapa Pesca e Aquicultura \\ Palmas/ Tocantins \\ BRASIL
}

E-mail: anapaula.rodrigues@embrapa.br

Received: $27-04-2017$

Accepted: 12-06-2017 